Sandpits and skipping ropes. I had not known any of the dead or injured. Why is a major disaster so important for the people who participate as helpers? I meet death almost every day of my working life. Was this worse or was it just larger numbers? Everyone sort of expects that an event like this will be upsetting. But why is it that more attention is focused on the feelings of helpers in such disasters than on those of people concerned with upsetting events that happen every day? For me it seems to have been a major shock to my system in a general sort of way. I was grumpy, washed out, and flat for a couple of weeks. Passing Hillsborough shocked me again when I had nearly rebuilt my professional defences.

All of us general practitioners who were there met a few times to talk about our experiences and to support each other. Why are all the others so articulate about how they are feeling whereas I'm just sort of nonspecifically upset? I can't remember what I felt like at the ground and can't describe to the helpful counsellor how I'm feeling during the group sessions. I know all the theory, but I can't get it together for myself-the plight of the modern professional. It's three weeks since the disaster now, and I'm feeling OK again; I make jokes at work and have lots to be thankful for. I've been enormously well supported through all this by family, friends, and colleagues. Time has passed and lessons to be learnt are being thought about. Perhaps British football has changed because of these events, and perhaps major disasters will be better dealt with in the future.

I'd like to tell the official inquiry in a systematic way what I think went right with the medical response that day and what I think could be done better next time. I don't know what training should be given to general practitioners and why none of us took charge of the medical happenings in the sports hall and was prepared to be the coordinator. I've got strong views about the counselling that is necessary and appropriate after the event for helpers at disasters. I'd like to do physical damage to the person who took the pictures for the Daily Mirror and reserve a special act of aggression for the person who allowed them to be published. But most of all I'd like to find out what happened to Terry.

\title{
Coming to terms with the death of a loved one
}

\author{
Rosemary Eccles
}

My first recollections of my future husband were shortly after arriving at university at a Christian Union meeting, where a tall, very handsome young man began to wheeze loudly and relieved his spasm with a noisy hand nebuliser. I was told that he had severe asthma and had struggled against many odds to reach university. It was only when, 18 months later, working closely on the Christian Union committee where our relationship matured that I realised the full extent of his past problems. I learnt that he had been one of the first asthmatic patients to be treated with oral steroids and this had enabled him to complete his A levels. I can remember clearly, some time after this, being in a chest clinic and seeing a man in his 40 s crippled by respiratory disease and being told about the prognosis of those with severe chest illnesses. At that time I began to consider the possibility that I was marrying someone who might leave me a widow at a young age.

New treatments for asthma, salbutamol and then sodium cromoglycate and beclomethasone dipropionate, soon gave such relief that the steroids were no longer necessary. Repeated attempts at withdrawal, however, and adrenal stimulation were ineffective, and he remained on them. The new inhalants meant life was normal and full. He embarked on a mountain leadership course, and we ran young people's adventure camps. As a pastor he worked hard building up a church from one member. I worked in community medicine and general practice and then returned to community medicine. About 15 years later quite suddenly his health began to deteriorate, and over the next few years he suffered the complications of long term steroid treatment. We began to face the possibility of his early retirement, and I took on more work. As his health failed his preaching became more powerful, and the church grew rapidly. Then one morning I woke to find him dead in bed.

Ribstone House, Hebden Bridge, West Yorkshire HX7 8BE

Rosemary Eccles, MB, senior community medical officer comfort to know that he was at peace with the God he so firmly believed in and had pointed others to. This also strengthened our children, and we were able to share together in preparing the service of thanksgiving.

\section{... people who were themselves bereaved were directed to me for help.}

And so, suddenly, my whole life was turned upside down; I faced the loss of my husband, the loss of my home for 20 years (it being tied to his job), and the immediate prospect of my children facing $\mathrm{O}$ and $\mathrm{A}$ levels in two weeks followed by a long holiday in America with relatives. This left the long summer holidays with an 8 year old with no one to look after her while I worked. I was plunged into a one parent family situation, needing to cope with my own grief and help my children with their needs.

\section{Coping with separation}

The oldest found the separation from us - going to America and then leaving home to go to university very hard. A natural coper with her own strong faith in God, she was torn between looking forward to college life in London and her new speech therapy course and wanting to be with us and help us at home. Moving while she was away was particularly difficult for her. The middle boy outwardly showed no effects. Even now he does not say much. Always a lad of few words and very "laid back" it has been hard to know how he feels. The biggest thrill was when he asked to be baptised and formally join our church. The youngest took it all bravely. At first she did not want to see her father but later asked to do so, the only one who did. She faced having to be parked out after school and going away to relatives in the summer holidays; she had had her father at home to look after her before. Now two years later she still clings a lot to me but is 
gradually becoming more independent. She spends a lot of time playing alone at home, but increasingly I hear her laughing and playing with her friends.

And what of myself? Having spent a lifetime helping others in both physical and spiritual needs, I found I was now the one in need, experiencing the shock and pain of sudden bereavement. It was hard to cope, comfort, and advise and give of myself while having such deep needs of my own. This conflict was worse when one by one people who were themselves bereaved were directed to me for help.

\section{The way ahead}

What were the things that helped me through this time? My own faith in a great God, who has said, "All things work together for the good of those who love him." My dog, who needed daily walks, enabling me to think, pray, and cry privately as I trudged through the woods and fields. My friends, many of whom invited us for meals and especially one who rang every night for a chat, allowing me to share the little and big things of each day at great sacrifice of time to herself. My children, who all share my faith, and so together we could face the many problems ahead in quiet confidence and trust in God. Those bereaved people who were directed to me for help. In helping them I could work through my own grief when otherwise I might not have had time to do so. My church; their first words were, "We want you to stay among us," and their love and support have continued to be a great comfort. It has allowed us to move nearby and so minimise the trauma of leaving our home. My colleagues at work, who have been very long suffering as I returned to work with only half a mind on my job and bore with me while I faced the ordeal of house hunting and moving. A viral illness, which laid me aside at a time when I was physically and emotionally drained, forcing me to have a month off work in which time I was able to recharge my batteries. My God, who has sustained me throughout and whose providential hand I can see in all that has happened to me in the past 25 years. I had always thanked him for my husband and the life we had together but always knew that even the deepest and closest relationships are a gift from God, not to be held on to or idolised. I thank God for helping me to give up one who was so dear to me and still see a meaning and purpose in my life ahead.

\section{When risk factors have little meaning}

So far in my short medical career I have worked on the premise that decision making is made easier by information. Good practice dictates that we strive to inform patients as fully as possible - before obtaining their consent for operation, when advising them on options for referral or treatment, and on everyday matters affecting their health. I often quote risk factors, and although I was aware of how little these figures may mean to a layman, until recently I had no idea just how irrelevant they could seem.

The question of amniocentesis came up in my second pregnancy because of my age. The risk of my having a baby with Down's syndrome was slightly greater than the risk of the procedure - that is, 1:200. This knowledge did not make the decision whether or not to have amniocentesis any easier. My husband and I talked at great length about whether we would be prepared to terminate our pregnancy at 20 weeks in the event of a positive result. We knew that we did not want an abnormal child, but neither did we want to go through a late termination. How should we go about guiding our feelings into rational, decision making thought? In the end we asked ourselves which would be worse - having no amniocentesis and having a child with Down's syndrome or losing a normal child as a result of the procedure? This helped us to balance the worst alternatives and we opted to have the amniocentesis.

All went well at first. The ultrasound scans were normal and the amniocentesis went smoothly with no untoward sequelae. The three weeks' wait for the result was not as bad as I had expected until I had the dream. I dreamt that we had been to see the obstetrician, who had been almost jovial.

"No need to worry. It is not Down's or anything like that, but there is something strange and we do need to do some more tests."

\section{Torturous wait}

I could not forget that dream. When the day came and we went to see the consultant I had a sense of deja vu when he told us that there was an extra piece of chromosome in the baby's karyotype. He could not say whether it was important without doing a few more investigations. The few days' wait for the results of tests on our chromosomes was little short of torture. We had been told that if one of us was carrying the extra bit of chromosome there was no problem. We spent three days trying not to think "What if not?"

\section{. . o our tears were tears of sorrow rather than of bitterness.}

When the answer came I was not very surprised that it was bad news-a new mutation and not hereditary. As the implications were not clear cut we were invited to see a clinical geneticist for advice and information. The extra genetic material was a centromere marker. The incidence is about one in 1000 . We were shown two papers on the subject. One looked at the results of 10000 amniocentesis results, ${ }^{1}$ and the other was a study of chromosomal abnormalities in patients in mental institutions of various kinds. ${ }^{2}$ We were told of a possible $10 \%$ risk of mental retardation in our child; the degree of impairment could not be predicted. We clutched at straws. The baby was moving and growing normally; two ultrasound scans had been normal. Were not these important signs? But then the baby would be physically normal even if mentally retarded. No comfort there.

We went home, holding the photocopies of the articles, our stunned minds a jumble of risk factors, fears, hopes, and uncertainty. For three days we talked, shed tears together, and tried to work out the answer. There were side issues that worried me constantly:

"What if my husband ended up feeling differently to me? How would I cope back at work after a termination when I had been so obviously pregnant? What would people think if we opted for ending the pregnancy?"

And above all the fear of going through a termination. I knew this should not affect my decision, but the thought of oxytocin drips, prostaglandin infusions, and regular papaveretum kept me awake at night. All my instincts told me to continue the pregnancy; my reason argued the case for termination. Our first child and her welfare became a major factor in the equation. 